УДК: 141.7

doi: 10.32620/gch.2019.4.08

Добридень О. В.

\title{
ДІАЛЕКТИКА ФОРМИ ТА ЗМІСТУ ЗДОРОВ'ЯЗБЕРЕЖУВАЛЬНОЇ АКТИВНОСТІ СОЦІАЛЬНИХ СУБ'ЄКТІВ В УМОВАХ СУСПІЛЬСТВА СПОЖИВАННЯ
}

У статті розглянуто особливості взаємодії форми та змісту здоров'я збережувальної активності соиіальних суб 'єктів в умовах суспільства споживання.

Ключові слова: здоров'язбережувальна активність, діалектика, форма, зміст, суспільство споживання.

The paper deals with the peculiarities of the interaction between the form and content of health preservation activity of social subjects under consumer society.

Keywords: health preservation activity, dialectic, form, content, consumer society.

Актуальність. 2019 року Всесвітня організація 3 охорони здоров'я традиційно обнародувала головні загрози для здоров'я населення планети, серед яких передусім забруднення повітря, неінфекційні захворювання, відмова від вакцинацій, стійкість до антибіотиків тощо. Беручи до уваги всю складність системних зв'язків у колі зазначених проблем, інтенсивність дискусії щодо охорони здоров'я не стихатиме й надалі. Тому не виникає жодних здивувань, чому безпека життєдіяльності людини в цілому й філософська рефлексія щодо феномена здоров'язбереження $є$ предметом критичного аналізу з боку багатьох сучасних дослідників.

Ступінь ефективності здоров'язбережувальної активності соціального суб'єкта залежить від цілої низки факторів. Кінцевий результат здоров'язбережувальної активності визначається не тільки розумовими й вольовими якостями того, хто іiі втілює в життя. Ідеться також про діалектичну взаємодію форми й змісту здоров'язбережувальної культури особистості, без яких неможливо уявити цілісне бачення зазначеної проблеми за сучасних умов. Як доречно зазначають В.П. Лисий i В.Г. Костенко, «розгляд 3 боку діалектики засновується на покладанні тї в якості цілого, а культура в такому випадку є їі момент. Інакше кажучи, діалектика (в логічному виразі), як ціле містить в собі культуру, але не в самостійному значенні, а в якості моменту, тобто діалектика як всезагальне, а культура є визначеністю цього загального» [9, с. 280].

Ступінь вивченості проблеми. Різноманітні аспекти проблеми здоров'язбереження й суспільства споживання стали об'єктом наукових пошуків зарубіжних і вітчизняних учених. Утім, здебільшого йдеться про непов'язаність понять у вивченні питань охорони здоров'я й масового споживання. Малодослідженим залишається коло проблем, що виникають унаслідок впливу ідеології суспільства споживання на здоров'язбережувальну діяльність людини. Різні 
аспекти зазначеної проблематики висвітлюються в роботах таких сучасних авторів, як О. Балуєва, А. Бойко, С. Бойко, П. Гусак, О. Завидівська, Н. Зимівець, Я. Зоська, Є. Кучеренко, О. Маруховська-Картунова, В. Петрович, А. Суббот, В. Морозова, А. Поляков, Ю. Сюсель, Н. Зленко, В. Халамендик, Ю. Бойчук, О. Цинтила.

Мета статті - визначити особливості взаємодії форми та змісту здоров'язбережувальної активності соціальних суб'єктів в умовах суспільства споживання.

Викладення основного матеріалу дослідження. Для кожної освіченої людини украй важливим $є$ розуміння реального стану речей у взаємозв'язках між елементами таких складних механізмів, як суспільство споживання та здоров'язбереження. Мається на увазі, що потужність негативних впливів на особистість суттєво збільшується, оскільки йдеться не про демонстративне витрачання коштів на непотрібний одяг і аксесуари, що зашкодить лише гаманцю споживача, а про витрати на здоров'язберігальні препарати, продукти й процедури. Отже, ідеться про вітальність біологічного організму людини й тривалість їі життя.

Перш ніж охарактеризувати особливості базових понять форми i змісту, звернімося до ознак сучасного соціокультурного простору, які їх зумовлюють.

Здоров'язбережувальна активність соціального суб'єкта в умовах сучасного консьюмеризму набуває специфічних атрибутів, форма і зміст яких зумовлюються вже традиційними соціальними практиками, притаманним суспільству надмірного споживання. Щодо споживацьких практик, які дедалі дужче вкорінюються в повсякденність буття людини, Н.М. Зленко цілком справедливо застерігає: «Уся концепція суспільства споживацтва спирається на новий тип особистості, сформованої не під впливом духовних сутностей і запитів, а виключно купівельною спроможністю та прагненням задовольнити потяги i бажання» [6, с.80]. На продовження цієї тези Я.В. Зоська та Б.А. Сторчовий слушно зазначають, вивчаючи вплив споживацтва на використання вільного часу українцями: «В умовах дефіцитарної економіки нашої країни споживацтво є девіацією, здійснює тотальний «зсув» цінностей» [7, с. 120].

Разом із входженням споживацьких практик у здоров'язбережувальну діяльність людини винятково гостро постало питання про інформаційне наповнення здоров'язбережувального культурного простору. Своєчасне спостереження 3 цього приводу робить А.О. Бойко: «Ідеологічна функція масової культури полягає в іiі здатності навіювати споживачам погляди, ідеї й уявлення, котрі конструюють розуміння навколишньої дійсності. Сучасний індивід, навіть будучи дуже освіченим, залишається фахівцем лише в якійсь окремій сфері. В інших галузях йому потрібна постійна допомога коментаторів, інтерпретаторів, учителів, журналістів, рекламних агентів та інших «гідів», які допомагатимуть йому долати безмежний простір інформації про суспільні події, культурні новації, альтернативи розвитку тощо» [1, c. 94].

Справді, у контексті міфічності чималої частки інформаційного поля сучасний період розвитку цивілізації можна охарактеризувати як вельми небезпечний для здоров’я людини. Оскільки фейкова інформація спрямовує людину до споживання 
шкідливих продуктів харчування, товарів і послуг. На думку С.В. Горової, «цінність інформації нерозривно пов'язана з ії корисністю, затребуваністю в перетворювальній діяльності людини. При цьому під корисністю розуміється роль інформації у забезпеченні існування й розвитку суспільства» [3, с. 218]. Одна справа, коли рекламні міфологічні сюжети не несуть у собі потенційні ризики здоров'ю. I зовсім інша річ, коли внаслідок фейкових інформаційних потоків відбувається застосування неякісних лікарських засобів, терапевтичних препаратів і процедур, а вживання продуктів харчування із вмістом шкідливих речовин призводять до руйнівних для здоров'я наслідків. Усі, хто має відношення до появи небезпечної продукції, а це науковці з їх винаходами й технологіями, виробники й постачальники, опиняються в ситуації, коли вони не просто сторонні спостерігачі, а безпосередньо сприяють зростанню захворюваності не серед абстрактної маси споживачів, а серед конкретних людей.

Приміром, такі сучасні синтетичні цукрозамінники, як аспартам (Aspartam, солодший за цукор у 200 разів) і неотам (Neotam, солодший за цукор у 13000 разів) використовуються у виробництві харчових продуктів. Аспартам, або Е 951, вільно продається через інтернет-ресурс і його вартість складає 578 грн за один кг. Харчова добавка Neotam, вартістю 100 американських доларів за 1000 кг, згідно з інформацією на сайті постачальника, використовується у виробництві морозива, тортів, газованих напоїв, джемів, десертів тощо, тобто у виробництві продукції, яка великою часткою належить до переліку продуктів харчування, що споживаються дітьми. Безсумнівно, якщо держава допускає використання синтетичних харчових добавок у продукції масового вжитку, особливо для дітей, то доречно говорити якщо не про зловживання, то про державно-управлінську недбалість. Державне управління у всіх сферах, що перетинаються 3 охороною здоров'я, потребує негайного переосмислення й вироблення компетентної стратегії здорового споживання задля здорової нації. Але, як слушно стверджує В.А. Жадько, «можна жити спільно в суто механістичному розумінні, в сенсі сумісно, в одному просторово-часовому вимірі, але не бути єдиними в духовно-світоглядному сенсі» [5, с. 80]. На превеликий жаль, можновладці живуть начебто в іншому вимірі буття, якщо прості речі, що перебувають на поверхні та від яких залежить здоров’я громадян, залишаються поза межами їхньої уваги.

У світлі управлінських здоров'язбережувальних стратегій цікавими є висновки, яких дійшла сучасна дослідницька група в монографії «Людський капітал: зміст і види, оцінка та стимулювання»: «Стан здоров’я людини - це їі природний капітал, частина якого є спадковою. Інша частина набувається в результаті намагань самої людини і суспільства. Протягом життя людини відбувається знос людського капіталу. Інвестиції, пов'язані з охороною здоров'я, здатні уповільнити цей процес. Проте, не всякі інвестиції в людину можуть бути визнані вкладеннями в людський капітал, а лише ті, які суспільно доцільні та економічно необхідні» [11, с. 185-186].

Як відомо, форма та зміст становлять зовнішню й внутрішню характеристику структури й організації певної системи. А.Ф. Поляков пропонує відштовхуватися від тези, що «субстанціальний параметр стверджує форму в якості матеріальної, а зміст і сенс в якості ідеальної складової» [10, с. 120]. У світлі здоров’язбережувальної 
активності акценти дещо зміщуються. Отже, за своєю суттю здоров'язбережувальна активність суб'єкта як одна з форм його повсякденного буття є сталою величиною, яка складається 3 певних сегментів, а саме догляду за фізичним і психологічним станом власного організму. Це означає, що за формою здоров'язбережувальна активність залишається незмінною, оскільки фізичні вправи й рух, дихальні практики, емоційна стійкість і аскетизм у харчових уподобаннях популяризувалися ще за часів стародавніх цивілізацій. Утім, форма, зберігаючи свої зовнішні сегменти, за своєю суттю стає ілюзорною внаслідок приголомшливої підміни справжніх елементів штучно-демонстративними в змісті здоров'язбережувальної активності.

Щодо демонстративної суті людській діяльності Є.В.Кучеренко правильно відзначає, що «глибинні корені демонстративного споживання носять як економічну, так і психологічну, соціальну та культурологічну природу. 3 одного боку, вони $\epsilon$ прагненням задоволення соціальних потреб і потреб у повазі та самовираженні, що має й економічне підгрунтя, а 3 іншого - способом вирішення особистих психологічних проблем у певному культурному середовищі» [8, с. 34]. Саме цей фактор демонстративної поведінки, який можна позначити як бажання жити не гірше за інших або, у світлі обговорюваної проблематики, піклуватися про власне здоров'я не гірше за інших, сприяє здійсненню здоров'язбережувальної активності за певними стереотипами. Проілюструємо підміну змістів у здоров'язбережувальній активності конкретним прикладом. У одному з багатьох рекламних сюжетів, завуальованому під інтерв'ю, відома українська акторка в невимушеній формі розповідає про користь уживання вітамінного комплексу відомого бренду. Швидше за все, для неї такий сюжет - це робота. Зрозуміло, що прихильники акторки, а ще й схильні до піклування про власне здоров'я, звертатимуть увагу саме на цей вітамінний комплекс. Але паралельно існує інформація, опублікована ВОО3, про високий рівень фальсифікованої продукції цього бренда на світовому ринку лікарських засобів. Проте, інформаційні повідомлення від ВОО3 не висять у вигляді попереджувальних оголошень в аптеках із зрозумілих причин. Отже, перед пересічними споживачами виникає потенційна загроза покупки неякісного препарату. Утім, уживання фальсифікованого вітамінного комплексу буде здійснюватися споживачем у межах його здоров'язбережувальної активності.

Як бачимо, відбувся безпрецедентний зсув понять. Уживати вітамінні комплекси i, приміром, кисломолочні продукти харчування корисно для здоров'я. За формою здоров'язбережувальної активності таке споживання належить до сегменту здорового харчування. Однак, якість справжнього й фальсифікованого продукту визначить кінцевий результат для здоров'язбереження окремого суб'єкта.

М.О. Шульга в монографії «Збій соціальної матриці» констатує: «Залежно від матеріального, освітнього, культурного, креативного, емоційно-вольового ресурсу люди, які виживають, організовують свою активність по-різному, тобто і в цих умовах вони мають, умовно кажучи, різні стилі життя. Це виглядає так, що в суспільстві співіснують різні уклади, різні стилі життя людей» [12, с. 97]. 3 огляду на здоров'язбереження повністю уникнути негативних впливів від технологій суспільства масового споживання не вдасться навіть за умови належної фінансової 
забезпеченості та культурного рівня соціального суб'єкта. П.М. Гусак, Н.В. Зимівець і В.С. Петрович цілком правильно наголошують, що «вибір ставлення до здоров'я - це особисте рішення, що безпосередньо впливає на здоров'я людини» [4, с. 24].

Особиста відповідальність у питаннях турботи про власне здоров’я завжди йтиме поруч iз самостійним критичним осмисленням інформації. I особиста відповідальність, і критичне осмислення грунтуються на освіті. Чим освіченішою $є$ людина, тим більше ії життєздатність і готовність до спротиву сучасним викликам. I те, що людина протягом життя може змінюватись у своїх поглядах, обнадіює. I.I. Ващинська бачить індивіда «унікальним та різним, як і його ідентичності, які значною мірою $є$ соціально сконструйованими у процесі соціалізації, соціальної інтеракції, завдяки чому індивіди визначають та перевизначають себе впродовж усього життя» [2, с. 35]. Погоджуючись із дослідницею, зазначимо, що саме ця здатність перевизначитись i уможливлює зміни у викривленому змісті здоров'язбережувальної активності соціального суб'єкта.

Висновки. Таким чином, унаслідок браку або за відсутності компетентної інформації про вміст, фальсифіковане походження й наслідки від споживання препаратів, продуктів харчування, товарів і процедур, зміст здоров'язбережувальної активності викривлюється, а форма, зберігаючи зовнішні сегменти, за своєю суттю стає ілюзорною.

\section{Література:}

1. Бойко А. О. Філософська рефлексія сучасної культури епохи суспільства масового споживання. Гуманітарний вісник ЗДІА. 2016. № 64. С. 90-99.

2. Ващинська I. І. Соціальні ідентичності та групові лояльності в сучасному українському суспільстві : дис. ... канд. соц. наук: 22.00.04. Львів, 2019. 302 с.

3. Горова С. В. Особа в інформаційному суспільстві: виклики сьогодення: монографія. Київ : НАН України, Нац. б-ка України ім. В. І. Вернадського, 2017. 452 с.

4. Гусак П. М., Зимівець Н. В., Петрович В. С. Відповідальне ставлення до здоров'я: теорія та технології : монографія. Луцьк, 2009. 219 с.

5. Жадько В. А., Бідзіля П. О. Філософське розуміння змісту соціальної медицини. Гуманітарний вісник ЗДІА. 2017. № 69. С. 77-84.

6. Зленко Н. М. Соціально-філософський аналіз теорії суспільства споживання. Філософія науки: традииї та інноващії. 2014. № 1 (9). С. 76-83.

7. Зоська Я. В., Сторчовий Б. А. Споживацтво українців: вільний час та практики його споживання. Соціальні технологї: актуальні проблеми теорії та практики. 2015. № 67-68. С. 113122.

8. Кучеренко Є. В. Сутність поняття «демонстративне споживання». Економічний вісник. 2017. №3. С. 28-36.

9. Лисий В. П., Костенко В.Г. Рефлексивний і категоріальний виміри співвідношення діалектики і культури. Науковий вісник ЛНУВМБТ імені С.3. Гжииького. Т. 16, № 3 (60), 2014. C. $278-285$.

10. Поляков А. Ф. Проблема понятийной триады «Форма - содержание - смысл». Вестник Бурятского государственного университета. 2014. № 6 (1). С. 118-121.

11. Человеческий капитал: содержание и виды, оценка и стимулирование: монография / Смирнов В. Т., Сошников И. В., Романчин В. И., Скоблякова И. В. М., 2005. 513 с. 
12. Шульга М. Збій соціальної матриці: монографія. Київ : Інститут соціології НАН України, 2018. $284 \mathrm{c}$.

\section{References:}

1. Boyko, A. O. (2016), Filosofs'ka refleksiya suchasnoyi kul'tury epokhy suspil'stva masovoho spozhyvannya [The philosophical reflection of the modern culture in the era of a mass consumer society], Humanitarnyy visnyk ZDIA, No. 64, pp. 90-99.

2. Vashchins'ka, I. I. (2019), Sotsial'ni identichnosti ta hrupovi loyal'nosti v suchasnosty ukrayins'komu suspil'stvi [Social identities and group loyalties in contemporary Ukrainian society], L'viv, $302 \mathrm{p}$.

3. Horova, S. V. (2017), Osoba v informatsiynomu suspil'stvi: vyklyky s'ohodennya [Man in the information society: challenges of today], NAN Ukrayiny, Nats. b-ka Ukrayiny im. V. I. Vernads'koho, Kyiv, $452 \mathrm{p}$.

4. Husak, P. M., Zimivets', N. V. and Petrovych V. S. (2009), Vidpovidal'ne stavlennya do zdorov'ya: teoriya ta tekhnolohiyi: [Responsible attitude toward health: Theory and Technology], Luts'k, $219 \mathrm{p}$.

5. Zhad'ko, V. A. and Bidzilya P. O. (2017), Filosofs'ke rozuminnya zmistu sotsial'noyi medytsyny [A philosophical understanding of the content of social medicine], Humanitarnyy visnyk ZDIA, No. 69, pp. 7784.

6. Zlenko, N. M. (2014), Sotsial'no-filosofs'kyy analiz teoriyi suspil'stva spozhyvannya [A sociophilosophical analysis of the theory of consumer society], Filosofiya nauky: tradytsiyi ta innovatsiyi, No. 1 (9), pp. 76-83.

7. Zos'ka YA. V. and Storchoviy B. A. (2015), Spozhyvatstvo ukrayintsiv: vil'nyy chas ta praktyky eho spozhyvannya [Consumerism of Ukrainians: leisure and consumption practices], Sotsial'ni tekhnolohiyi: aktual'ni problemy Teoriyi ta praktyky, No. 67-68, pp. 113-122.

8. Kucherenko, Ye. V. (2017), Sutnist' Ponyatiya «demonstrative spozhyvannya» [The essence of the concept of «demonstrative consumption»], Ekonomichnij visnyk, No. 3, pp. 28-36.

9. Lysyy V. P. and Kostenko V. H. (2014), Refleksyvnyy y katehorial'niy vymiry spivvidnoshennya dialektyky y kul'tury [Reflective and categorical measurements of the relationship between dialectic and culture], Naukovyy visnyk LNUVMBT imeni S. Z. Gzhits'koho, Vol. 16, No. 3 (60), pp. 278-285.

10. Polyakov, A. F. (2014), Problema ponyatiynoyi triady «forma-zmist-sens» [The problem of the conceptual triad «form - content - meaning»], Visnyk Buryat's'koho derzhavnoho universytetu, No. 6 (1), pp. $118-121$.

11. Smyrnov V. T., Soshnykiv I. V., Romanchin V. I. and Skoblyakova I. V. (2005), Lyuds'kyy kapital: zmist $i$ vydy, otsinka ta stymulyuvannya [Human capital: content and types, evaluation and stimulation], Moscow, $513 \mathrm{p}$.

12. Shul'ha M. (2018), Zbiy sotsial'noyi matrytsi [The social matrix failure], Instytut sotsiolohiyi NAN Ukrayiny, Kyiv, 284 p.

\section{Oksana Dobryden}

\section{THE DIALECTIC OF FORM AND CONTENT OF HEALTH PRESERVATION ACTIVITY OF SOCIAL SUBJECTS UNDER CONSUMER SOCIETY}

According to the World Health Organization, the major health threats to the planet's population are air pollution, non-infection diseases, vaccine refusal, antibiotic resistance, etc. Taking into account the whole complexity of the systemic links in the range of these issues, the 
discussion intensity on health will continue. That's why, there's no wonder the safety of human life as a whole and the philosophical reflection on the phenomenon of health are the subject of critical analysis of many modern researchers.

The extent, to which a social subject's health-preserving activity is effective, depends on a number of factors. The end result of health preserving activity is determined not only by the mental and volitional qualities of the person who puts it into practice. It is also a matter of the dialectical interaction of form and content of a personality's health preserving culture, without which it is impossible to imagine a holistic vision of this problem under the current conditions.

Health preserving activity of a social subject under the contemporary consumerism acquires specific features, the form and content of which are predetermined by traditional social practices that are inherent in a society of over-consumption.

It is of utmost importance for every educated person to understand the real state of affairs in the interconnections between the elements of such complex mechanisms as a consumer society and health preservation. It means that the power of negative effects on the individual is being significantly increased, because it is not about demonstrating expenses on unnecessary clothes and accessories, which will harm only the consumer's wallet, but about expending on health-preservation drugs, products and procedures. That is, the vitality of the human biological organism and the duration of their life are crucial.

Personal responsibility to care about your own health will always go hand in hand with critical reflection on the information. Both personal responsibility and critical thinking are based on education. The more educated a person is, the greater his or her vitality and readiness to meet the challenges of today are.

Thus, as a result of the lack or the absence of competent information on contents, false origin and consequences of the consumption of preparations, foods, goods and procedures, the content of the health-preserving activity is being distorted, and the form, while preserving external segments, becomes illusory in its essence.

Keywords: health preservation activity, dialectic, form, content, consumer society.

\section{Оксана Добридень}

\section{ДІАЛЕКТИКА ФОРМИ ТА ЗМІСТУ ЗДОРОВ'ЯЗБЕРЕЖУВАЛЬНОЇ АКТИВНОСТІ СОЦІАЛЬНИХ СУБ'СКТІВ В УМОВАХ СУСПІЛЬСТВА СПОЖИВАННЯ}

За даними Всесвітньої організації з охорони здоров'я, до головних загроз здоров'ю населення планети належать забруднення повітря, неінфекційні захворювання, відмова від вакцинацій, стійкість до антибіотиків тощо. Беручи до уваги всю складність системних зв'язків у колі зазначених проблем, інтенсивність дискусії щодо охорони здоров'я не стихатиме й надалі. Тому не виникає жодних здивувань, чому безпека життєдіяльності людини в цілому й філософська рефлексія щодо феномену здоров'я збереження $\epsilon$ предметом критичного аналізу з боку багатьох сучасних дослідників.

Ступінь ефективності здоров'язбережувальної активності соціального суб'єкта залежить від цілої низки факторів. Кінцевий результат здоров'язбережувальної активності визначається не тільки розумовими й вольовими якостями того, хто ії втілює в 
життя. Ідеться також про діалектичну взаємодію форми і змісту здоров'язбережувальної культури особистості, без яких неможливо уявити цілісне бачення зазначеної проблеми за сучасних умов.

Здоров'язбережувальна активність соціального суб'єкта в умовах сучасного консьюмеризму набуває специфічних атрибутів, форма i зміст яких зумовлюються традиційними соціальними практиками, які притаманні суспільству надмірного споживання.

Для кожної освіченої людини украй важливим є розуміння реального стану речей у взаємозв'язках між елементами таких складних механізмів як суспільство споживання та здоров'язбереження. Мається на увазі, що потужність негативних впливів на особистість суттєво збільшується, оскільки йдеться не про демонстративне витрачання коштів на непотрібний одяг і аксесуари, що зашкодить лише гаманцю споживача, а про витрати на здоров'язбережувальні препарати, продукти й процедури, тобто про вітальність біологічного організму людини та тривалість їі життя.

Особиста відповідальність у питаннях турботи про власне здоров'я завжди йтиме поруч із самостійним критичним осмисленням інформації. I особиста відповідальність, i критичне осмислення грунтуються на освіті. Чим освіченішою є людина, тим більше їі життєздатність і готовність до спротиву сучасним викликам.

Таким чином, унаслідок браку або за відсутності компетентної інформації про вміст, фальсифіковане походження й наслідки від споживання препаратів, продуктів харчування, товарів і процедур, зміст здоров'язбережувальної активності викривлюється, а форма, зберігаючи зовнішні сегменти, за своєю суттю стає ілюзорною.

Ключові слова: здоров'язбережувальна активність, діалектика, форма, зміст, суспільство споживання.

Добридень Оксана - кандидат філософських наук, доцент, завідувач кафедри гуманітарних наук Державного закладу «Дніпропетровська медична академія Міністерства охорони здоров'я України».

Dobryden Oksana - Ph.D. in social philosophy, Associate Professor, Head of Departament of human studies, Dnipropetrovsk Medical Academy of the Ministry of Health of Ukraine.

e-mail: o.v.dobryj@gmail.com

Надійшла до редакції 17.10.2019. Розглянута на редколегії 19.11.2019.

\section{Рецензенти:}

Кандидат біологічних наук, професор, завідувач кафедри фізичної культури гуманітарного факультету Національного аерокосмічного університету ім. М. Є. Жуковського «Харківський авіаційний інститут» Дусенко Д. І.

Кандидат економічних наук, доцент, доцент кафедри права гуманітарного факультету Національного аерокосмічного університету ім. М. Є. Жуковського «Харківський авіаційний інститут» Раздіна О. В. 